\title{
New Books from Springer Publishing House
}

DOI: $10.1134 / \mathrm{S} 1061934809030198$

Surface Analysis of Glasses and Glass Ceramics and Coatings, Series: Schott Series on Glass and Glass Ceramics, Bach, H. and Krause, D., Eds. Springer, 2009, 950 pp.

Nagahara, L., Tao, N., and Thundat, T., Introduction to Nanosensors, Series: Nanostructure Science and Technology, Springer, 2008, 450 pp.

Basic Principles of Forensic Chemistry, Khan, J., Christian, D., Jr., and Kennedy, T.J., Eds., Springer, 2008, 416 pp.

Baia, M., Astilean, S., and Iliescu, T. Raman and SERS Investigations of Pharmaceuticals, Springer, 2008, 220 pp.

Functional Nucleic Acids for Analytical Applications, Series: Integrated Microanalytical Systems, Li, Y. and Lu, Y., Eds., Springer, 2008, 300 pp.

Standardization and Quality Assurance in Fluorescence Measurements State of the Art and Future Challenges, vol. 5. of Springer Series on Fluorescence, Resch-Genger, U., Ed., Springer, 2008, 700 pp.

Michler, G. H., Electron Microscopy of Polymers, Series: Springer Laboratory, Springer, 2008, 420 pp.

Fluorescence of Supermolecules, Polymers, and Nanosystems, vol. 4. of Springer Series on Fluorescence, Berberan-Santos, M.N., Ed., Springer, 2008, XVIII, $468 \mathrm{pp}$.

Mirceski, V., Komorsky-Lovric, S., and Lovric M., Square-Wave Voltammetry: Theory and Application,
Series: Monographs in Electrochemistry, Springer, 2007, VIII, $201 \mathrm{pp}$.

Cell Separation: Fundamentals, Analytical and Preparative Methods, vol. 106. of Advances in Biochemical Engineering / Biotechnology, Kumar, A., Galaev, I.Yu., and Mattiasson, B., Eds., Springer, 2007, XIV, 203 pp.

Advanced Environmental Monitoring, Kim, Y.J. and Platt, U., Eds., Springer, 2007, XXII, 422 pp.

van den Berg, A. and Andersson, H., Lab-on-Chips for Cellomics: Micro and Nanotechnologies for Life Science, Springer, 2007, XVI, 363 pp.

Creative Chemical Sensor Systems, vol. 277 of Topics in Current Chemistry, Schrader, T., Ed., Springer, 2007, XIII, 303 pp.

Verma, H.R., Atomic and Nuclear Analytical Methods: XRF, Mössbauer, XPS, NAA, and Ion-Beam Spectroscopic Techniques, Springer, 2007, XIV, 375 pp.

Analytics of Protein-DNA Interactions, vol. 104 of Advances in Biochemical Engineering / Biotechnology,. Seitz H., ED., Springer, 2007, XI, 204 pp.

Grundler, P., Chemical Sensors: An Introduction for Scientists and Engineers, Springer, 2007, IX, 273 pp.

Piezoelectric Sensors, vol. 5 of Springer Series on Chemical Sensors and Biosensors, Steinem, C. and Janshoff, A., Eds., Springer, 2007, XII, 483 pp.

N.B. Zorov 